\title{
A Short Memoir of Ito Keisuké, Rigaku Hakushi (Doctor of Philosophy) ${ }^{1}$.
}

\author{
BY \\ TOKUTARO ITO, D.Sc. \\ With a Portrait (Plate XXII).
}

$\mathrm{HE}$ following translation of M. Tokutaro Ito's valuable
memoir of his celebrated grandfather is for the most part a full one, but occasionally omission and compression have been exercised. It is hoped that it will be found interesting, as the memoir of a Japanese botanist of Old as well as of New Japan, who was also one of the principal pioneers of western science in Japan, written by a Japanese for Japanese readers.

M. Tokutaro Ito's memoir was originally published ir the Toyo Gakugei Zasshi (Journal of Oriental Science and Art) in 1898 .

I have to thank my friend Mr. Kumagusu Minakata for help in reading some of the proper names and in other ways.

The rendering of Japanese titles, many of which are new since I left Japan twenty years ago, has given me considerable trouble, and I am not sure that I have always hit upon the exact English equivalents-perhaps because they do not exist.

F. V. D.

1 The editors are much indebted to Mr. F. Victor Dickins for translating the original Japanese memoir, and to Dr. Tokutaro Ito for readily consenting to its publication.

[Annals of Botany, Vol. XIV. No. LV. September, 1900.]

E e 
The venerable Doctor's name is Keisuké. He is known also as Kinkwa, and again as Seimin ${ }^{1}$. Lastly he calls himself Taikosan Sho (a faggot of Mt. Taiko) after a country residence he possesses of that name in the village of Ueno, in the district of Aichi, in the province of Owari ${ }^{2}$.

$\mathrm{He}$ was born on the 27 th of New Year's month ${ }^{3}$ of the $3^{\text {rd Kyowa }}{ }^{4}$ (A.D. I803) in Gofuku ${ }^{5}$ Street in Nagoya in Owari. His father, Nishiyama Gento, followed the profession of medicine. His mother's name was Noma. There were three sons and one daughter of the marriage. The eldest son was called Sonshin, the second son was the venerable doctor. Sonshin entering the family of Okochi, Keisuke became the heir. In his youth he was called Nishiyama Sachu, but in accordance with his father's wish the name was discarded and the old family name of Ito was resumed. Following in the footsteps of his father and elder brother, he adopted the profession of medicine. From boyhood he was fond of collecting plants and inquiring their Chinese and Japanese names from his father and brother.

In Bunkwa and Bunsei ${ }^{6}$, in company with Mizutani Sukeroku he made a tour through the provinces of Owari, Mikawa, Isé, Shima, Mino, and Shinano, collecting plants, animals, and minerals.

In $182 \mathrm{I}$, being nineteen years old, he went to Kyoto and made the acquaintance of many well-known botanists. With

\footnotetext{
${ }^{1}$ In Old Japan most writers, artists, \&c. assumed various literary or artistic names at different periods of their life. The family name came first always-thus Ito Keisuké, now commonly written Keisuké Ito.

2 The Japanese names of provinces are given. The Japanese, after an apparently arbitrary fashion, call some provinces by their native, others by their Chinese, names. Thus Owari is more often known as Bishu.

${ }^{3}$ I make this date, according to the old calendar, to be Feb. 20 , 1803 .

4 A nengo or year-period of Old Japan. These had more or less fanciful Chinese names. Kyowa might mean Enjoyment of Peace. In 1867 the nengo was named Meiji (Illustrious Rule) and is to be conterminous with the reign of the present Emperor.

${ }^{5}$ Gofuku means 'clothes.' It is a Chinese word, the literal signification of which is 'Go ( Wu ) clothing,' indicative of $\mathrm{Wu}$ as one of the sources whence Chinese civilization was introduced into Japan.

${ }^{6}$ Bunkwa, I804-17. Bunsei, I818-29.
} 


\section{Rigaku Hakushi (Doctor of Philosophy). 403}

the help of the venerable Fujibayashi Taisuke he began the study of foreign learning. From time to time he botanized in the hill-tracts of Hiyei, Kibuné, Kurama, and Atago, and in the following years in the provinces of Yamashiro, Settsu, Yamato, Isé, Shima, Mikawa, Totomi, and Suruga. He was then invited to Yedo, and enjoyed the hospitality of the venerable Udagawa Yoan ${ }^{1}$, with whom he spent a month collecting in Nikko, whence he returned to his native Nagoya by Haruna and Myogi in Kozuke, and Kiso in Shinano. A little earlier the German botanist $\mathrm{Ph}$. Fr. von Siebold had arrived in Japan and taken up his residence at Nagasaki. In 1826 , desiring to behold the Shogun's court, he went up to Yedo, and on the way, at Atsuta, a coolie-relay station in Owari, met Mizutani Sukeroku and Okochi Sonshin, together with the venerable subject of this memoir-to the great pleasure and profit of all, as one may well believe. The meeting is mentioned in Siebold's Nippon:- 'Ich lernte hier die meinen Untersuchungen später so nützlich gewordenen Ito Keiské und Okutsi Sonsin kennen' (Siebold: Nippon, vol. i, Abteilung I, p. I68). Ito Keisuké could scarcely bear to part from Herr von Siebold, and accompanied him as far as Narumi. When they separated, von Siebold expressed his great desire to see his fellow traveller again at Nagasaki, and thenceforth Ito Keisuké could not rest until he had gained permission from his father and elder brother to make the journey to Nagasaki. It was with no little delight he set out on the journey, and in his old age he often recalled the pleasure he felt, and frequently spoke to the present writer of the delightful anticipations of that time. In 1827 , in the 9th month, being in his $25^{\text {th }}$ year, he arrived at Nagasaki, and lodged in the house of the Chief Interpreter Yoshio Gonnosuké. He lost no time in calling upon von Siebold, who was delighted to see him again. The whole of the time

1 Udagawa Yoan was a very remarkable man, who took a large part in introducing western science to his countrymen. He published a work on seimi (chemie) in 1837 (Seimi Keiso), and earlier still, in 1834 , an elementary treatise on western botany, Shoku-gaku Keigen. 


\section{Tokutaro Ito.-A Short Memoir of Ito Keisuke,}

spent at Nagasaki, from the first day to the last, in the spring of the following year, was occupied in botanical work with the German botanist. We can well picture to ourselves how delightful he must have found such an intercourse. At this time, von Siebold occupied a house in a part of Deshima known as Hanabatake (the Garden Ground), about one cho (6o ft.) square filled with plants native and foreign, grown for examination. The beds were arranged by von Siebold himself in rows symmetrically placed opposite each other, and must have presented a very agreeable appearance. The house was an ordinary upper-storied Japanese dwelling. The venerable doctor went there daily to prosecute his studies. At this time there was a gate at the entrance to Deshima occupied by a guard (saguriban-examining watch) consisting of several yakunin ${ }^{1}$, who searched the folds and sleeves of every person who passed in or out. Ito was allowed to carry his herbaria and packets of plants in and out, but these had to be searched each time; in fact scientific investigations were then carried on under many difficulties scarcely realizable by men of science at the present day. Among Ito Keisuke's fellow students at Nagasaki were Kō Ryōsai, Takano Choyei ${ }^{2}$, Oka Kennosuké, Kaku Saichiro, and Hayashi Dokai.

After a stay of some six months Keisuké was recalled home by family affairs. Herr von Siebold was sorry to lose him, and gave him as a farewell gift a treasured copy of Thunberg's Flora Faponica, bidding him use it diligently as a help to his studies. His pupil passed through Kiushu and Banshu, collecting plants on the way, and on reaching Nagoya resumed the practice of medicine, but whenever he could find time read Thunberg diligently and made it the foundation of his further studies, in the first place collating the Latin names with the Chinese and Japanese names of native plants, so as to adjust and complete their nomenclature.

With the aid of Thunberg's work, and in the light of the

1 Rather a European than an ordinary Japanese designation of a Bakufu official.

2 Takano Choyei was a man of considerable ability. He was among the first to recognize the value of the English alliance. He was prosecuted and finally committed suicide. He was posthumously raised to the fourth class last year.-K.M. 


\section{Rigaku Hakushi (Doctor of Philosophy). 405}

Systema Naturae of Linnaeus, he prepared his Taisei Honzo Meiso ${ }^{1}$ in 3 vols., which he presented to his Daimyo in 1829. Herr Nordenskiold, in his Voyage of the Vega, referring to Thunberg's Flora, gives a portrait of the venerable doctor [as he then appeared?]. On the covers of this work, with the object of correcting a popular error, Keisuké represented a yamabuki fruit (Kerria Faponica) and an ichijiku flower (Ficus) accompanied by a line from an old poem-

\section{'Mi no hitotsu dani naki zo kanashiki!'}

Not so much as a single fruit to be seen, alas ${ }^{2}$ !

With the desire of introducing the Linnean system into Japan, Udagawa Yoan had some time before explained it in a book called Botanika kyo, published in 1822 , but unfortunately the work was little noticed. Our venerable doctor much regretted this neglect, and in 1879 desired me to reprint it together with the Seisetsu kuwansho kyo of Yoshio Shunzo published also in 1822 . When Herr von Siebold returned home he took with him over ten portfolios of dried plants given him by Ito Keisuké, which are now preserved in the Leiden Museum. Professor Geerts refers to this collection in the following words :-

'Mr. Ito Keiské, le célèbre botaniste Japonais, qui a le premier observé et décrit une quantité de plantes nouvelles, et enrichi le musée de Leyde d'un herbier fort intéressant et très-précieux. Il a publié en $\mathrm{I} 823$ une traduction critique de la Flore Japonaise de Thunberg, comprenant trois volumes in-8 ${ }^{\circ}$. Ce livre intitulé Tai-sei-hon-zo-mei-su est très-difficile à trouver aujourd'hui chez les libraires de Kiyoto ou de Yédo' (Geerts: Les Produits de la Nature, vol. i, Introduction, I876).

1 A list of Ito Keisuké's works is appended to the memoir.

2 The Stanza is in the Kokinshu (Poems Old and New ; Ioth Century) :-

Nanaye yayé

hana wa sakedomo

Yamabuki no

mi no hitotsu dani naki zo kanashiki.
The seven-petalled, the eight-petalled

Flower! though it bloom

on the Yamabuki, yet never a fruit, not so much as a single fruit doth it show, alas the Yamabuki!

The Japanese notion (derived from China) was that Kerria had no fruit and Ficus no flower. 
Professors Hoffmann, Miquel, and Schultes examined these portfolios, and Professor Miquel gave an exhaustive description of the Herbarium Botanici versatissimi, Itoo Keiské, in prov. Owari ins. Nippon degentis, Sieboldi amici, forma octava maxima XIII volumina (quaedam alia deperdita).

On his return to Nagoya from Nagasaki Ito Keisuké began to practise medicine on the Dutch system. At this time the Chinese system was in vogue, and the innovation was looked at askance, in fact was suspected of sorcery, and the physician incurred some odium.

Disregarding this danger, Ito persisted in his efforts to promulgate Dutch learning and science, now explaining the grammar and collecting vocabularies of Dutch, now insisting upon the advantages of vaccination, or setting forth the principles of chemical science and the progress of western philosophy. Meanwhile he prosecuted the new system of medicine until at last pupils began to gather around him and patients to besiege his doors. For forty years he continued to practise foreign medicine at Nagoya, but in the intervals of leisure afforded during a busy career, showed a sustained interest in natural science. In $183^{2}$ and $183^{8}$ he botanized in Shinano, in $185^{2}$ and 1855 in Omi, Yamashiro, Settsu, Isé, and Shima, in conjunction at various times with Yoshida Heikuro and Iinuma Yokusai ${ }^{1}$.

In 1827 he established a Museum of Pharmacy in Nagoya, and later in $185^{8}$ a Physic Garden in the same town and a Natural History Museum.

In 1837 a famine raged in Japan. Moved by the pitiable condition of the distressed people, our venerable doctor wrote a pamphlet (Kiuko Shokubutsn Benran) on Edible Plants which the Daimyo, struck by its utility, ordered to be printed, and caused thousands of copies to be circulated throughout his fief in the provinces of Owari, Mikawa, and Mino. The next year a great fire occurred in Yedo, and the Nishimaru quarter of the Castle (seat of the Bakufu Government) was burnt down. To procure hinoki (Chamaecyparis) timber for rebuilding the

1 Author of the well-known Somoku Zusetsn (Illustrated Flora). 


\section{Rigaku Hakushi (Doctor of Philosophy).}

castle, a government commissioner was associated with an officer of the han (fief), and hundreds of coolies were collected to explore the forests of Mt. Kiso, of which opportunity Ito availed himself to study the flora of the district, accompanying the party as medical officer. For several months he lived in a hut and diligently searched hill and valley for plants, finding many rare and interesting specimens.

Ito, as already mentioned, had previously given much attention to western learning, and explained the essentials of foreign languages. In I84I he published his Yojihen for the use of beginners, as a result of which very many persons desirous of acquiring foreign languages sought his aid. In 1847 he was made a Chief Superintendent to the Daimyo (Goyonin shihai), and the year after was much occupied with editing and translating important foreign works. About this time he revised the Nagara-gawa Kijishi and arranged the Hyochu Shisho. He also translated Salmon's Nihon hen and wrote a treatise on foreign saltpetre, founded on a Dutch work.

In 1852 he was appointed a Vaccination Inspector, and began his duties with the establishment of a station at Nagoya.

At this juncture rumours were rife of the coming of a foreign squadron, and great was the confusion and consternation they caused. Ito ordered three hundred cannon to be cast and presented them to the Daimyo, receiving a large sum of money by way of reward.

In 1854 , when the foreign ships appeared, he was appointed a secretary, and afterwards furnished much information on foreign affairs.

In I 858 he reprinted the Oranda Chiri Shoho (Geographisch Zakboekje), upon which he afterwards founded his Yochi kiryaku (Short Account of our Globe) for the use of beginners.

In 1859 he was nominated a medical adviser, and a teacher of the art of translation from foreign languages. The next year he was made a member of the Banshochosho (office for examining barbarian writings), and called to Yedo to take part in the duties of the department of Products and Manu- 
factures. In the next year he was rewarded with five pieces of silver on account of his diligence in promulgating vaccination. In 1863 von Siebold returned to Japan and settled at Yokohama, where the Bakufu sent Ito Keisuké to report upon the subject of natural science. Herr von Siebold was delighted to see his old friend again. The same year Ito Keisuké was obliged, through ill-health, to resign his office in the Banshochosho, and returned to his native town. At this time cholera (bosha) was ravaging the country, and he issued a small handbook of precautionary measures which was widely circulated. In I 865 the Daimyo appointed him his family physician. After the Restoration, in 3rd Meiji (1870), he was nominated an official by the new Government, and was summoned to the capital to be created a member of the University, with the degree of sho hakushi [sort of licencie essciences].

In 187 I he was given a professorial appointment under the Ministry of Education. He afterwards became Deputy Assistant Compiler (henshu gonnosuké), and in 1872 received 7 th class rank, being specially employed in the section of Natural Science. He was appointed Compiler (Henshukwa) in 1873. He was now busy with his Nippon Sambusshi, of which he officially published six parts, dealing with the provinces of Yamashiro, Musashi, and Omi. In 1874 he gave to the world the first part of the Herbs section of the Nippon Shokubutsu Zusetsu-Illustrated Japanese Flora-the preparation of which had occupied him during many years. His son, who had previously written on Pharmacy and Elementary Botany, compiled the index. Professor Geerts thus refers to the work:- 'Mais il nous faut surtout parler du dernier ouvrage que vient de publier, malgré son grand âge, Mr. Ito Keiské, en collaboration cette fois avec son fils, Mr. Ito Udzuru. C'est le Ni-honshoku-butsu-dzuye, ou Description des plantes Faponaises encore inconmues. Dans le premier volume de cet ouvrage, publié en $1874, \mathrm{Mr}$. Ito Keiské a décrit et dessiné environ une cinquantaine de plantes nouvelles découvertes par lui. Ces plantes n'avaient été déterminées d'une manière 


\section{Rigaku Hakushi (Doctor of Philosophy). 409}

aussi exacte dans aucun ouvrage Japonais. Mr. le Docteur Savatier a écrit une préface pour ce livre, et il y fait à juste titre un grand éloge du zèle et du savoir du doyen des botanistes Japonais contemporains. Dans ce dernier travail de Mr. Ito Keiské, le nom scientifique figure en caractères romains à la suite de la plupart des plantes qui y sont décrites. Espérons que le vénérable savant vivra encore assez pour continuer et terminer cet ouvrage si intéressant et si utile' (Geerts, loc. cit. p. 37).

In 1877 he was made extraordinary Professor of Philosophy (science) in the Tokyo University, and appointed to a special post in connexion with the Botanical Gardens. In addition he undertook duty in relation to the Educational Museum.

The same year he completed the first part of the Koishikawa Shokubutsu-en Somoku Mokuroku, and further instalments of the Nippon Sambusshi.

In 1880 he became a Director of the Koishikawa Gardens, and published the second part of the Mokuroku. The next year he was made a Professor in the University. In collaboration with Kaku Hika, the brother of Kaku Saichiro, he published the first volume of the Koishikarwa Shokubutsu-en Somoku Zusetsu, and in the following year the second volume appeared. In 1879 he had been elected a Fellow of the Tokyo Gakushi Kwai-in (Tokyo Academy of Learning). He afterwards published in the Journal of the Society an essay on the 'Rise and Course of Natural Science in Japan,' and a paper called Kwashi zakki (Botanical Notes). Other articles of his may be found in the Transactions of the Yoyosha (Society for promoting Culture, founded about 1872 by the well-known publicist, Fukuzawa and others).

His 'Edible Plants' and 'Poisonous Plants' were mentioned in the Krvampo (Official Gazette). In I 880 he received a silver medal from the Royal Academy of Stockholm, in $\mathbf{I} 88_{\mathbf{I}}$ a second class medal from the International Geographical Congress at Venice, and in the same year he was elected a corresponding member of the N. China Branch of the Royal Asiatic Society. 
4 IO Tokutaro Ito.- A Short Memoir of Ito Keisuké,

In 1877 and $188 \mathrm{I}$ he was appointed an Inspector of the Exhibition of National Industries. In 1887 he was made a member of the $4^{\text {th }}$ class of the Order of Merit. In I 888 the degree of Doctor of Philosophy (Rigaku Hakushi) was conferred upon him, and in 1893 he was raised to the lower fourth official rank (Fushii).

The venerable botanist has discovered many new Japanese plants-to not a few of which his name has been given, as to the shimobashira called Keiskea by Prof. Miquel.

He has now attained his ninety-sixth year, and is still hale and hearty. His interest in systematic botany is undiminished, and he shows no sign of flagging powers. He still has by him hundreds of unpublished papers on botanical subjects, by-products of the labours of a long life.

Translated by F. Victor Dickins.

May I 7, 1900.

Ito Keisuké, I rejoice to say, is still alive in his ninetyeighth year. He has lately been selected by his countrymen as one of 'the Twelve Heroes of Modern Japan.'-F.V. D. 


\section{A List of Ito KeISUKÉ's PRINCIPAL WoRKS.}

1. Taisei Honzo Meiso : Western Botanical Nomenclature, 3 vols., i829.

2. Kiuko Shokubutsu Benran : Handy Book of Edible Plants, I837.

3. YoJI HEN : Book of Foreign Characters, I vol., I84I.

4. Nagaragawa kijishi : Poems in praise of the River Nagara, 2 vols., 1848.

5. Hyochu Shisho: A Collection of Loyal Poems, 3 vols, 1850.

6. SHOSEKI HEN : Treatise on Saltpetre, 3 vols., 1854 .

7. Boshabyo Te-Atì: Handbook of Precantionary Measures against Cholera, I vol., I 863 .

8. Nippon (or NiHon) Sambusshi : Products of Japan, i I vols., I873-1877.

9. Koishikawa Shokubutsu-en Somoku Mokuroku : Catalogue of Plants in Koishikawa Gardens, 2 vols., I 877 -1880.

10. Koishikawa Shokubutsu-en Somoku Zusetsu : Illustrated Description of Plants in Koishikawa Gardens, 2 vols., I88I-I884.

11. Kinko Shokubutsu Shusetsu: Edible Plants (Government Edition), i 884.

12. Yodoku Shokubutsu, Shusetsu : Poisonous Plants (Government Edition), I884.

13. KinkWA KOGWA FU : An account of ancient tiles (an antiquarian work by Kinkwa, one of the names of Ito Keisuké), in the I6th volume of the Journal of the Tokyo Academy of Science, 1894.

14. Salmon's 'Nihon hen': Perhaps this is No 395 of Pagès, Bibl. Jap., 'Salmon, Th., Tegenw. staat der keizerrijken China en Japan, uit het Eng. ver., Amst. I 729, met pl. en kaarten.' 


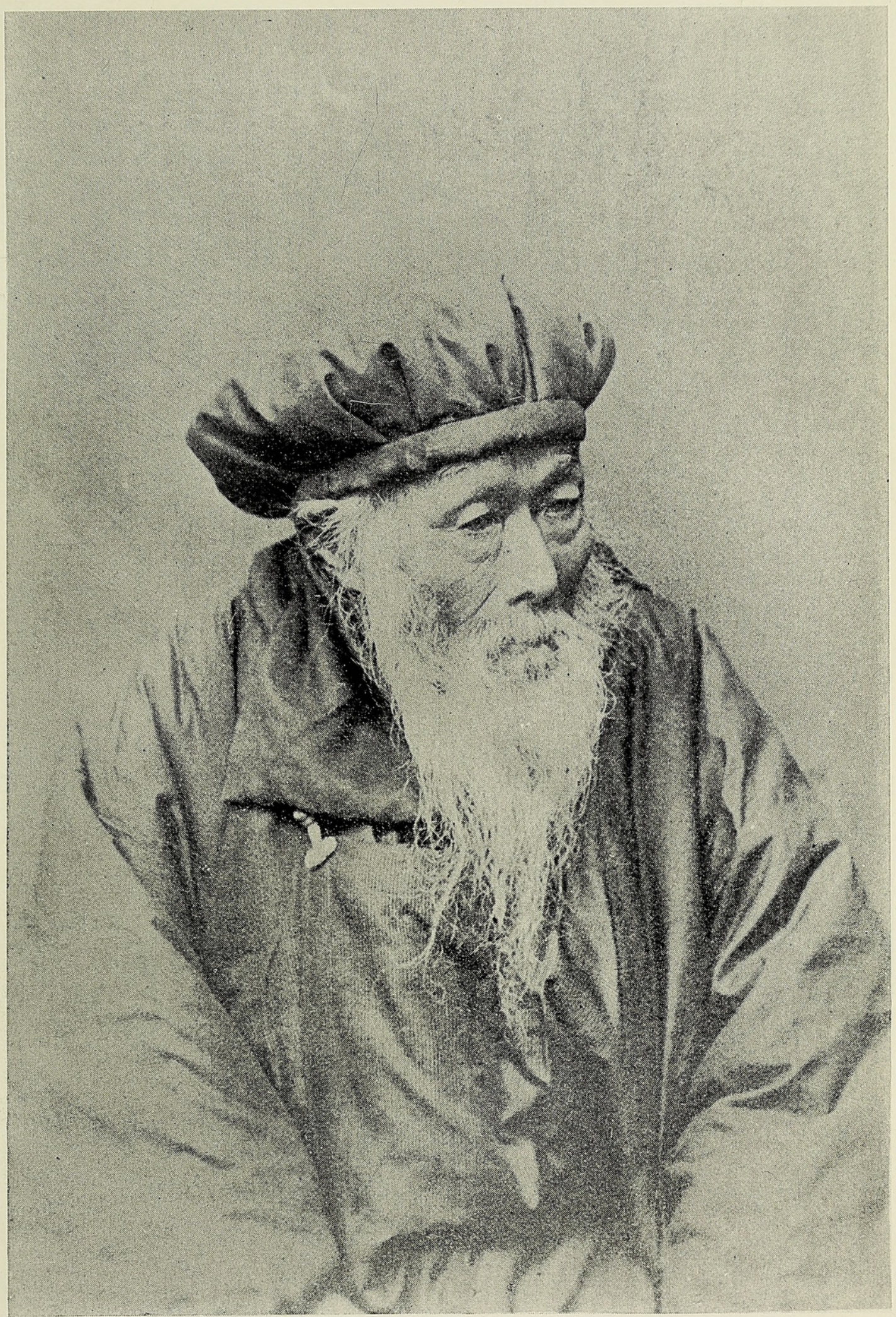

ITŌ KEISUKÉ, KNOWN AS THE VENERABLE KINKWA

AgE 96 (IN I898) 

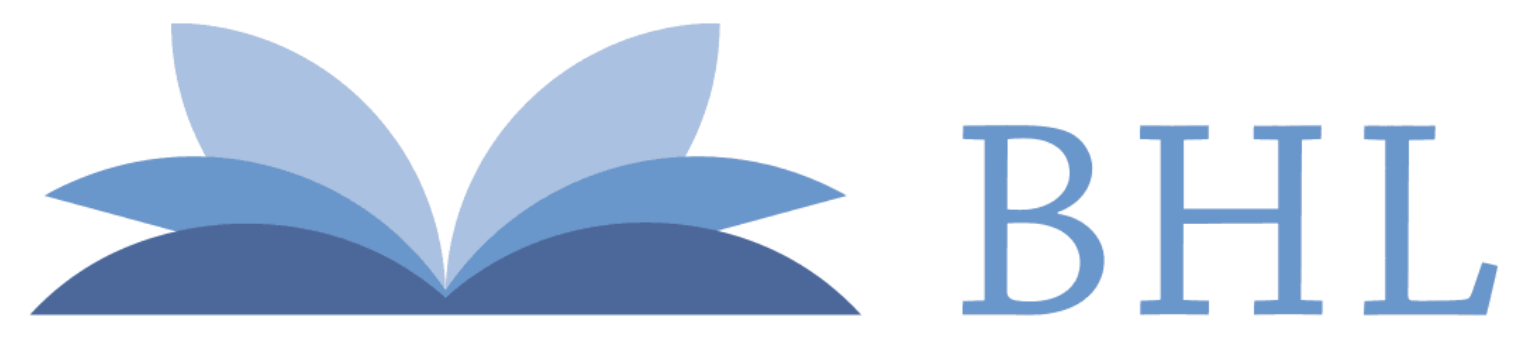

\section{Biodiversity Heritage Library}

Ito, Tokutaro. 1900. "A short memoir of Ito Keisuké, Rigaku Hakushi (Doctor of Philosophy)." Annals of botany 14, 401-411. https://doi.org/10.1093/oxfordjournals.aob.a088786.

View This Item Online: https://www.biodiversitylibrary.org/item/238259

DOI: https://doi.org/10.1093/oxfordjournals.aob.a088786

Permalink: https://www.biodiversitylibrary.org/partpdf/318593

\section{Holding Institution}

Smithsonian Libraries

\section{Sponsored by}

Biodiversity Heritage Library

\section{Copyright \& Reuse}

Copyright Status: Not in copyright. The BHL knows of no copyright restrictions on this item.

This document was created from content at the Biodiversity Heritage Library, the world's largest open access digital library for biodiversity literature and archives. Visit BHL at https://www.biodiversitylibrary.org. 